\title{
Histopathology of Trypanorhyncha plerocercoids (Cestodes) in some Marine Fish from Waters of the Arabian Gulf
}

\author{
M.M. IBRAHIM \\ Animal Health Research Institute, Dokki, Cairo, Egypt
}

\begin{abstract}
In March, 1997, 150 fresh fish specimens from the waters of Arabian Gulf, 95 of fish belonging to Groupers, Epinephelus aerolatus (local name Simman) and the other 55 fish specimens belonging to Emperor lethrinus sp. (local name Sheiry) were subjected to parasitological examination. Free floriceps Trypanorhyncha plerocercoids larvae were found in the flesh, while encysted forms of these larvae were found in the body cavity and mesenteries. The incidence of infection was higher in the Lethrinus sp. (34.5\%) than Epinephelus sp. (24.2\%). Intensity of infestation in the muscular tissues was higher in the muscles of the caudal peduncle; head and around the vertebral column than in the abdomen and trunk regions. Histopathology of the infected muscular tissues showed pronounced tissues destruction with intensive inflammatory reaction characterized by focal degenerative and necrotic changes with evidence of hemorrhages and cellular infiltration mainly lymphocytes. Over 350 encysted plerocercoids blastocysts of floriceps sp. could be counted from the peritoneal cavity and around the internal organs in heavy infested fishes with signs of fibrosis and adhesion.
\end{abstract}

\section{Introduction}

The growing importance of fish as a protein source, and interesting in exporting fishery products to the markets with high quality standards requires knowledge of fish health in the exploited stocks, Palm (1997). In the coastal water of the Arabian Gulf, Groupers, Epinephelus aerolatus (local name Simman) and Emperor, Lethrinus sp. (local name Sheiry) are considered of the most commonly seen in the markets, and highly prized food fishes. They are predatory fishes which eat crustaceans and small fishes. Cestodes parasitic infection involving

\footnotetext{
*Present address: $\quad$ Fisheries Research Center, El-Qataif, Eastern Province, Saudi Arabia.
} 
fishes has become host specific. The larval stages of Trypanorhynchs plerocercoids (cestodes) were a worldwide distribution in many marine fish species (Oppenheimer, 1962; Overstreet, 1977; Reimer, 1981; Petersen et al., 1993 and Palm, 1997). The presence of migrating larval cestodes of Trypanorhyncha in the flesh of the infected fish pose a potential marketable problems (Deardoff $e t$ al., 1984 and Palm, 1997). Infection with Trypanorhyncha induced extensive pathological changes that were evident in the infected host (Moser et al., 1984). There was no much information on Trypanorhyncha cestodes infestation in marine fish from water of the Arabian Gulf and studies were limited (El-Naffar et al., 1992; Al-Ghais and Kardousha, 1994). In March, 1997, during the course of routine examination for the fish health condition of some marine fishes from the water of the Arabian Gulf at a large fish market in El-Qataif at the Eastern Province of Saudi Arabia, the inspectors noticed heavy infestation with free living parasitic worms in the flesh of Epinephelus Groupers, Epinephelus aerolatus (Simman) and Lethrinus sp. So the aim of the present study is to present data on the rate and distribution patterns of infestation with Trypanorhynchs larval cestodes in the musculature and visceral organs in the infected fish species and provide information on the histopathological alteration induced by host parasitic interaction.

\section{Materials and Methods}

In March, 1997, 150 fresh fish samples, 95 of them belonging to Groupers, Epinephelus aerolatus (Simman) and the other 55 fish samples belonging to Lethrinus sp. (Sheiry), were harvested from the Coastal water of the Arabian Gulf. Fishes were examined carefully, dissected; filleted and slices were taken from the infested parts of the flesh, examined carefully and parasites were collected and pressed between two glass plates to make the parasites easily to be visible and examined under a light source. The body cavity as well as internal organs were carefully searched for the presence of the parasitic worms larvae with the help of a stereoscopic microscope with $6 \times$ magnification. All postlarval free or encystic plerocercoids parasites were collected, washed in saline and fixed in $70 \%$ alcohol and stained with acetic carmine, dehydrated and mounted in Canada balsam (Lucky, 1997) for identification.

For histopathology, representative samples from infected fish flesh as well as internal organs were fixed in $10 \%$ buffered formalin. Routinely processed to paraffin wax, and 5 um sections stained with hematocyline and eosin (H \& E) (Carleton et al., 1962).

Examined fish of Lethrinus sp. were range from $(55-63 \mathrm{~cm})$ in long and with an average weight (2.150-4 kg) while Epinephelus aerolatus were of (67-80 $\mathrm{cm})$ in long and with an average weight (4-9 kg). 


\section{Results}

\section{Clinical Observation}

The morphological examination of muscular tissues of the freshly Epinephelus aerolatus and Lethrinus fish spp., indicated the presence of very conspicuous and extensive numbers of free living parasitic worms larvae, while in the body cavity, mesenteries and around the internal organs as well as gonads, the larvae were seen either free or forming encysted plerocercoids containing well develop scolex. The examined fishes did not show any external visible disease sign.

\section{Parasitic Identification}

According to the fundamental work and classification of Campbell and Beveradge (1994); Palm (1977), and based on the assistance of Dr. Palm at the Institut fur Meereskunde, an der Universitat Kiel, Germany, the present parasitic worms larvae, infection was identified as Trypanorhyncha Plerocercoid of Floriceps sp. (cestodes), which characterized by a mature scolex bearing four retractable and reversible strong tentacles armed with hooks and two bothridia (Fig. 1).

\section{Incidence of Infection}

It was found out of 95 specimens of Epinephelus aereolatus, 23 fish samples were found to be infected with an incidence (24.2\%), while out of 55 fish samples of Lethrinus sp., 19 samples were found to be infected with an incidence $(34.5 \%)$.

\section{The Clinical Alteration and Histopathology}

\section{1 - In the muscular tissues}

The free living larval stage of Trypanorhyncha plerocercoids (cestodes) of floriceps sp. were long white in color range from $(7-12 \mathrm{~cm})$ in long, deeply embedded in the flesh of the infected hosts (Fig. 2) forming grooves or tunnels and firmly attached to the muscular tissues. The distribution and intensity of the migrating larvae of floriceps sp. in the flesh of the examined fish revealed high numbers of infestation in the caudal peduncle, around the vertebral column and head (13-15 worms larvae in numbers). A moderate to low numbers of infestation (7-10 in numbers) in the trunk region, while low infestation in numbers (35 worms larvae) in the belly muscles. Infestation and size of host fish relationship were existed. Heavy infestations were noticed specially in the largest size fishes (63 cm in Lethrinus sp. \& $80 \mathrm{~cm}$ in Epinephelus sp.), while the smallest 


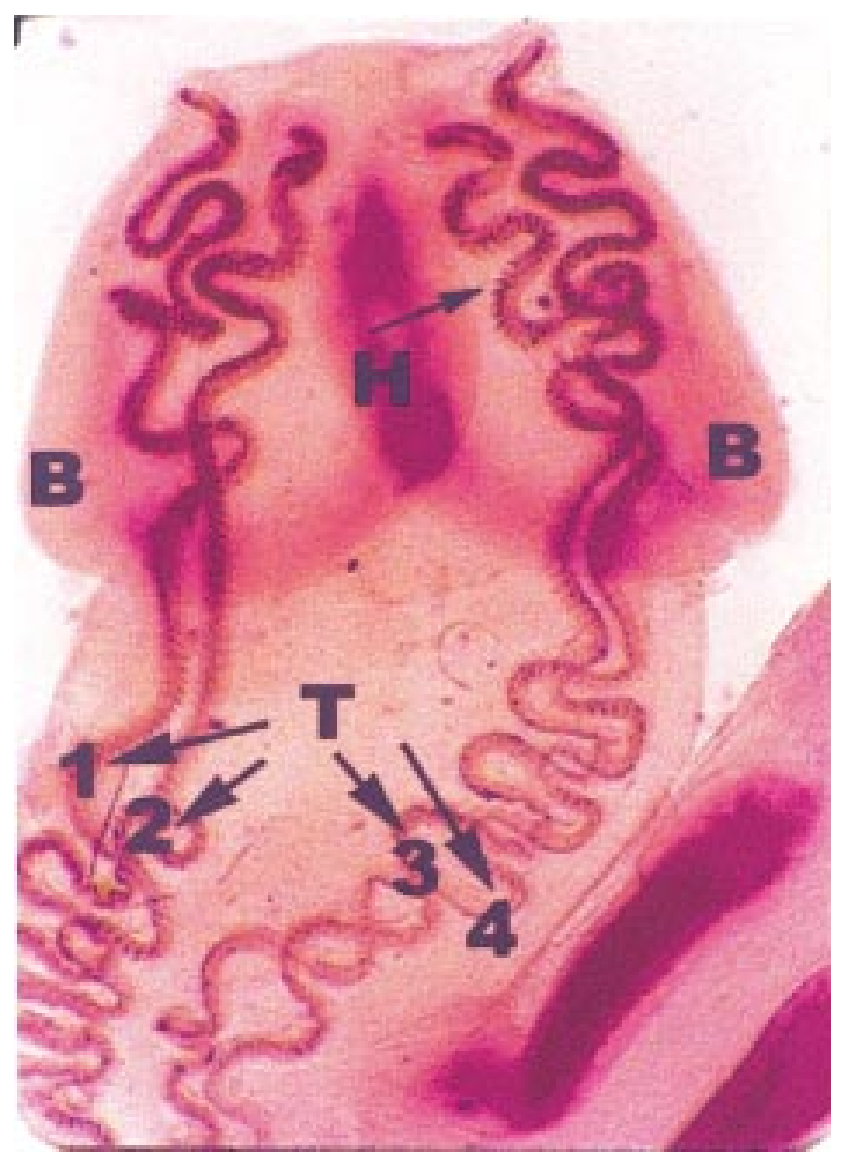

FIG. 1. The parasitic worm larvae of Floriceps plerocercoid Trypanorhynch (cestode), showed well developed head (Scolexbearing four reversible strong tentacles (T: 1,2,3,4), armed with hooks $(\mathrm{H})$, and two Bothridia (B). Acetic-carmine stained $\times 400$. 


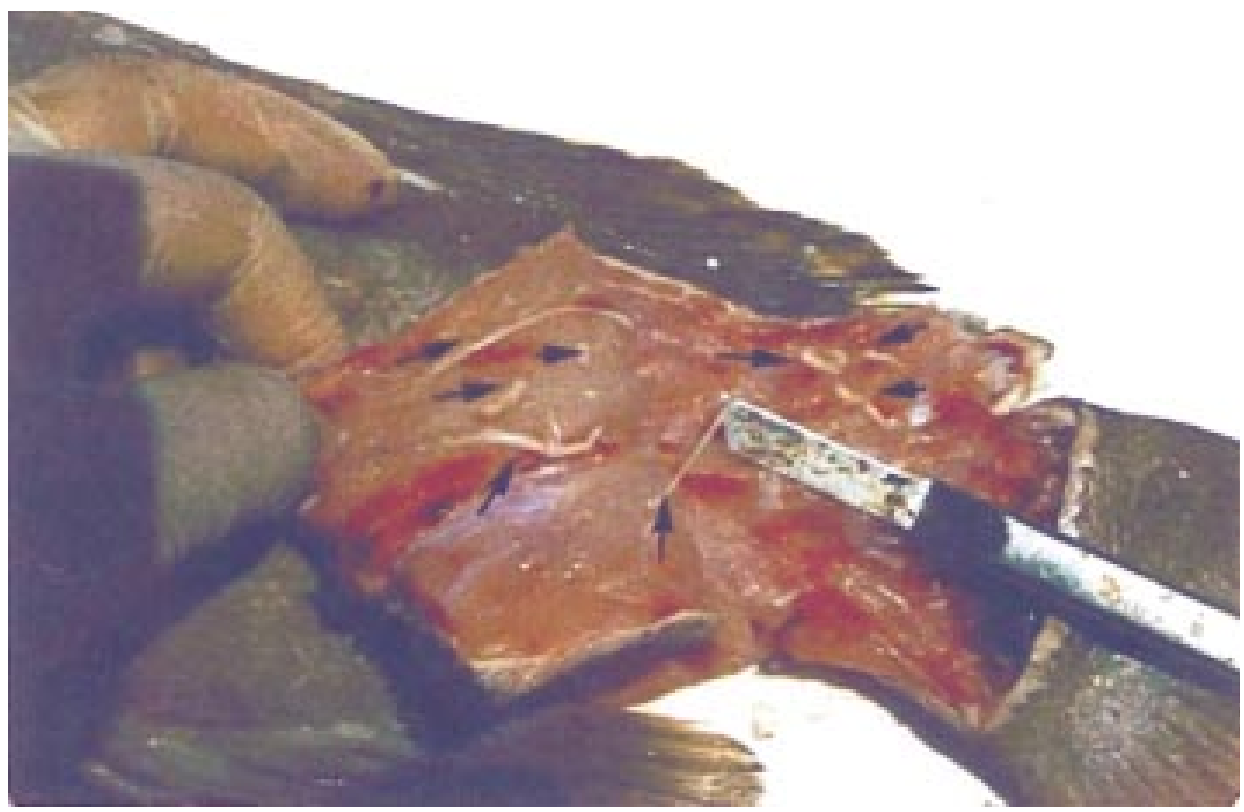

Fig. 2. Infected fish sp. showed heavy infestation with free white parasitic worms larvae of trypanorhynch plerocercoid (arrows) in the muscles of the caudal peduncle.

size of the same species harbored few in numbers. The average numbers of infestation with free parasitic worms in the flesh/fish were ranged from (18-25 larvae/ fish) in both kinds of the examined fish species specially in large size hosts.

Histopathology of the flesh inhabiting Trypanorhynchan plerocercoids of floriceps sp. larvae showed pronounced tissues destruction and damages with intensive inflammatory reactions specially at the entrance of the motile viable burrowing scolex. Focal degeneration and necrotic changes in the myofibres with extravasation of erythrocytes and cellular infiltration mainly lymphocytes (Fig. 3). The tunnels induced by the perforating larvae in the muscular tissues were consisted of slight connective tissues wall around the motile viable larvae, while the adjacent muscular tissues suffered from dystrophic changes (Fig. 4).

\section{2 - In the body cavity and mesenteries}

The encysted plerocercoids (blastocysts) of floriceps sp. in the body cavity and mesenteries of the infected fishes species (Fig. 5) were elongated range from small size (few in $\mathrm{mm}$ in long) to large size ones up to (12 cm in long). The old and long blastocysts appeared with blunt border anteriorly containing highly developed head portion of the worm larvae and with tapering posterior end (Fig. 6). In some cases the blastocysts were seen whitish in color without 


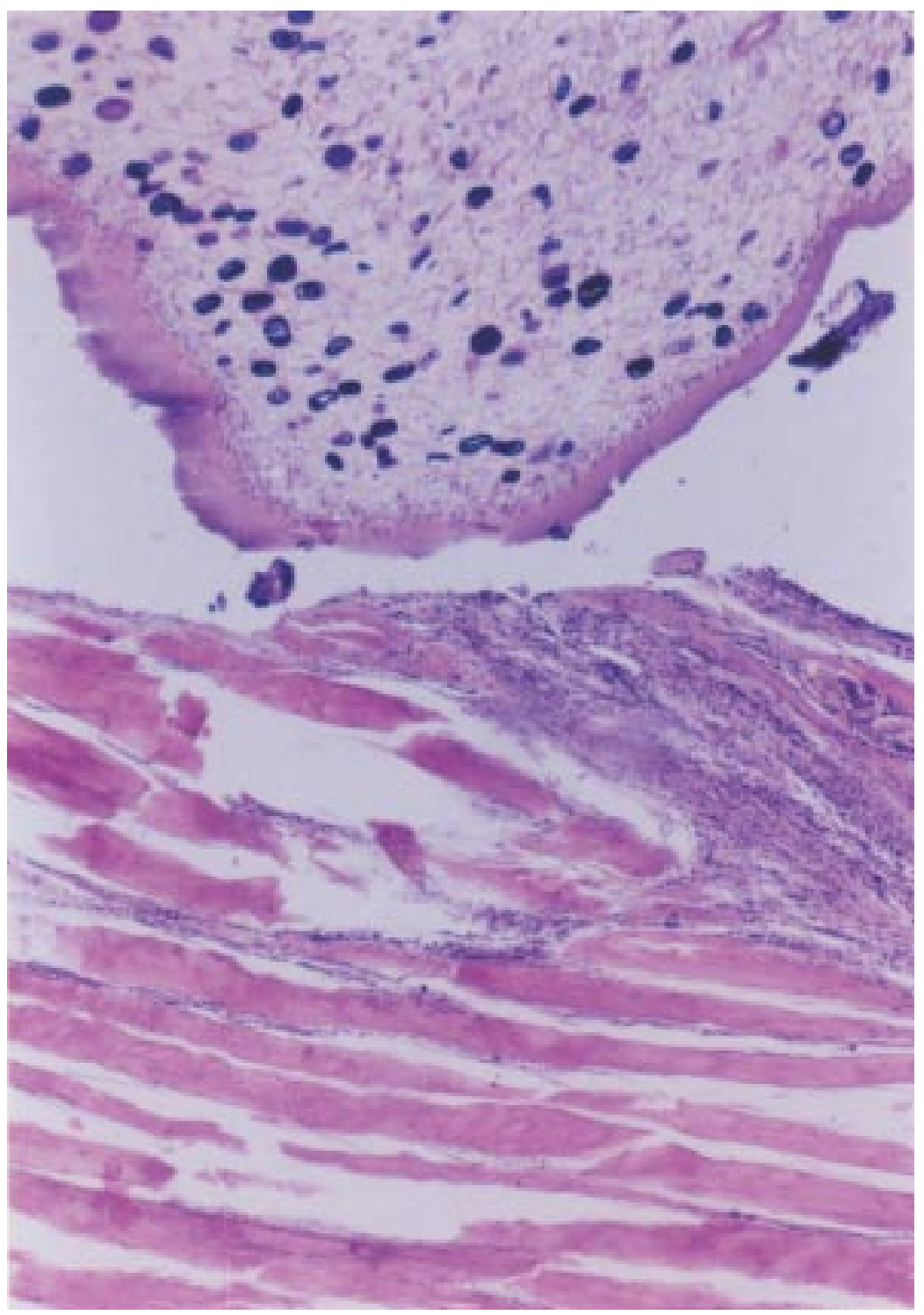

罗

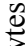

을

文

츨

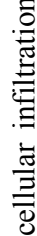

责

.ృ 
Histopathology of Trypanorhyncha plerocercoids (Cestodes) in some...
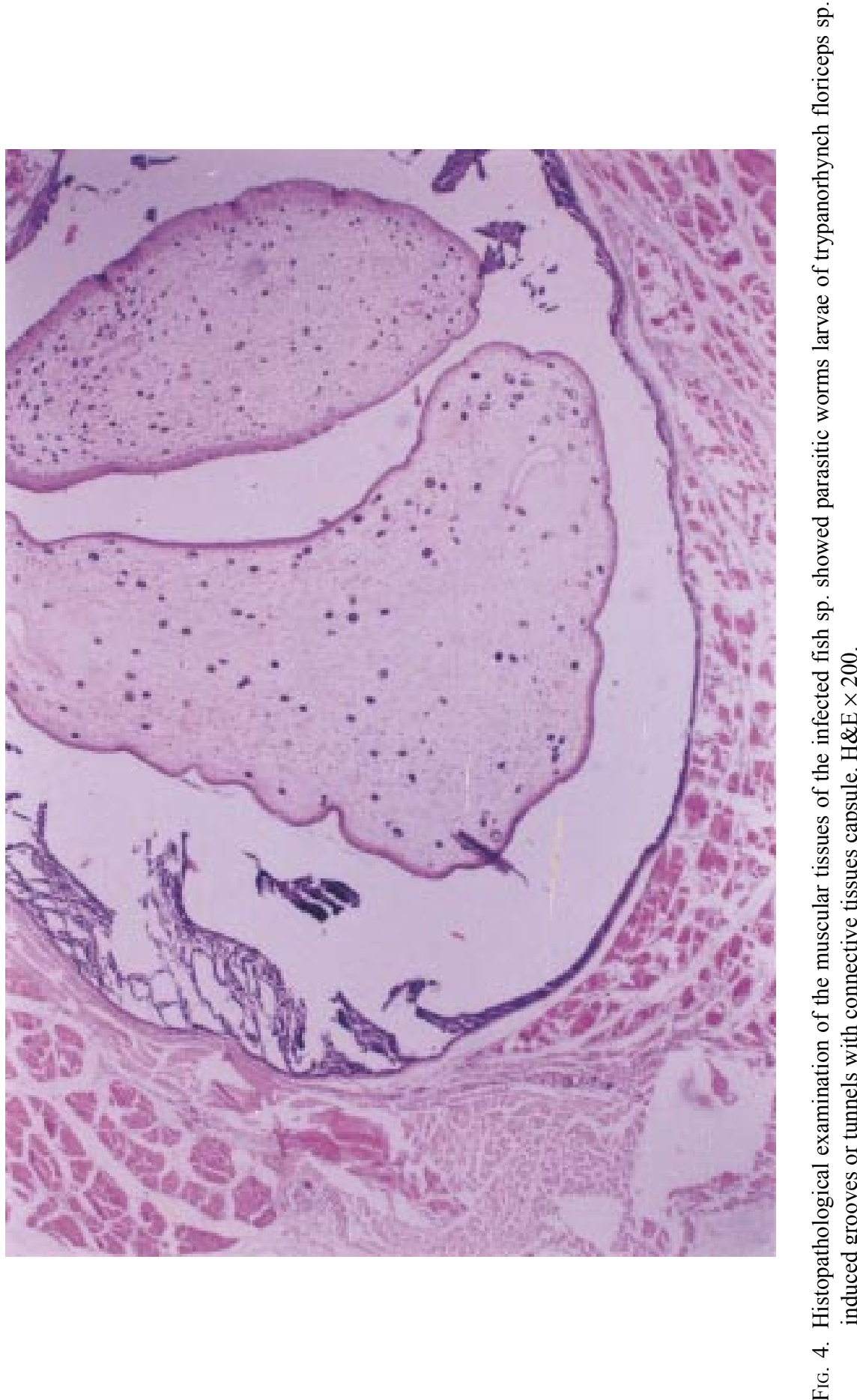


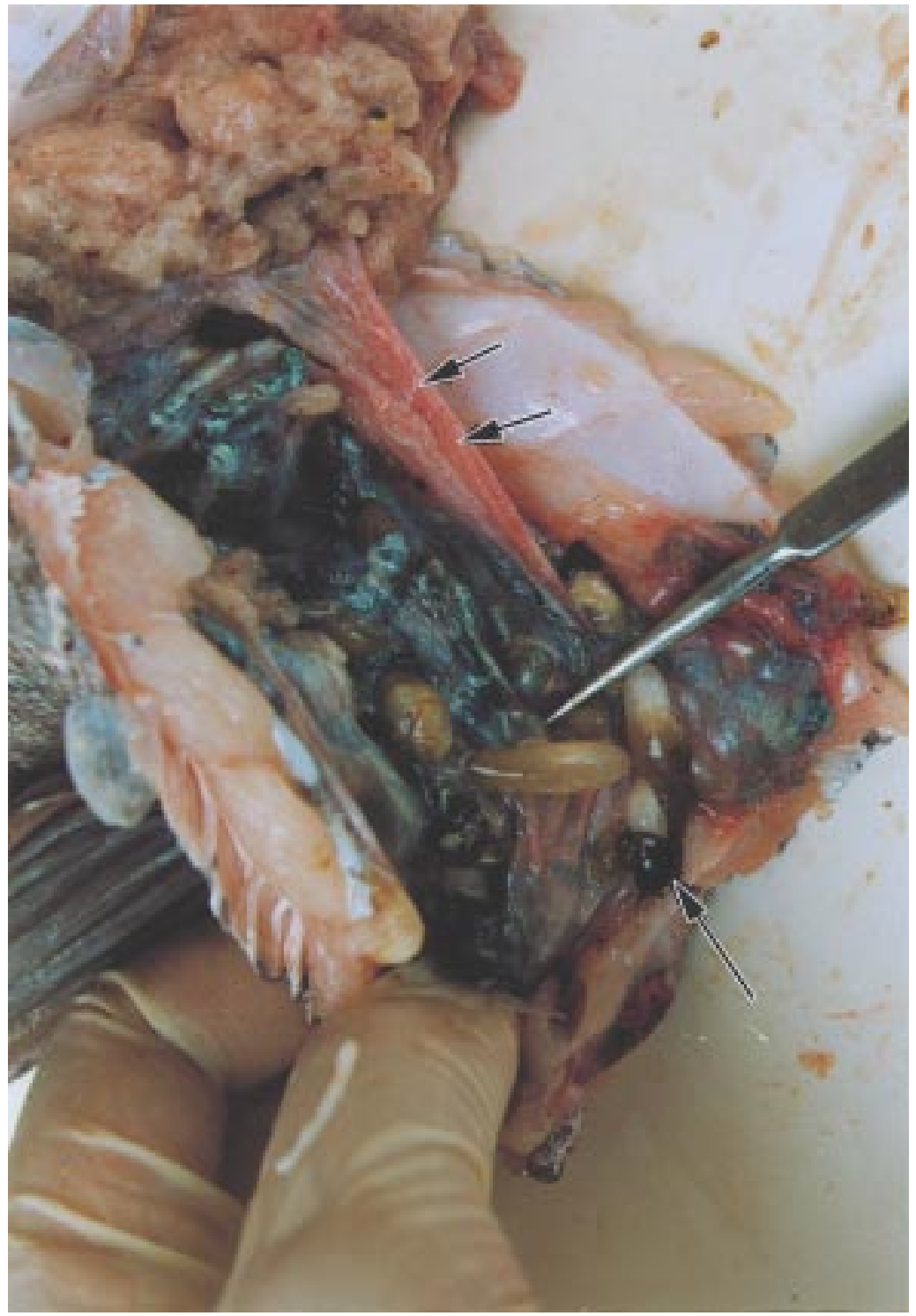




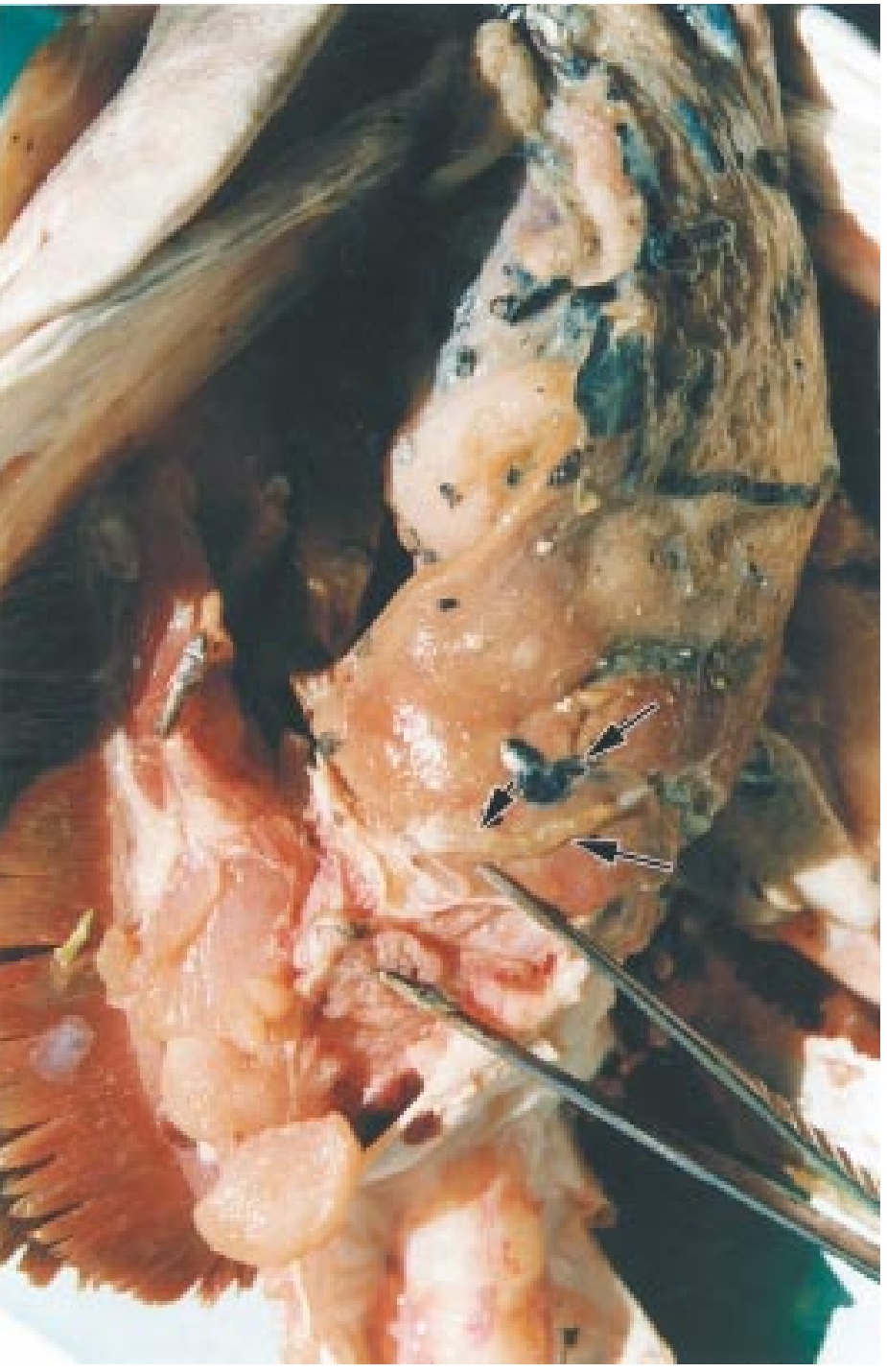


any covering coat, while other were encapsulated covered with a thick deep brown to black envelop. Over 300-350 encysted plerocercoid blastocysts could be counted specially in large size infected fishes with sings of severe adhesion of the peritoneal wall and internal organs associated with engorgement of the mesenteric blood vessels.

Histologically, the encysted plerocercoids (blastocysts) showed capsules of fibrous connective tissues proliferation contained larvae and cellular infiltration mainly lymphocytes as well as dilation of mesenteric blood vessels (Fig. 7).

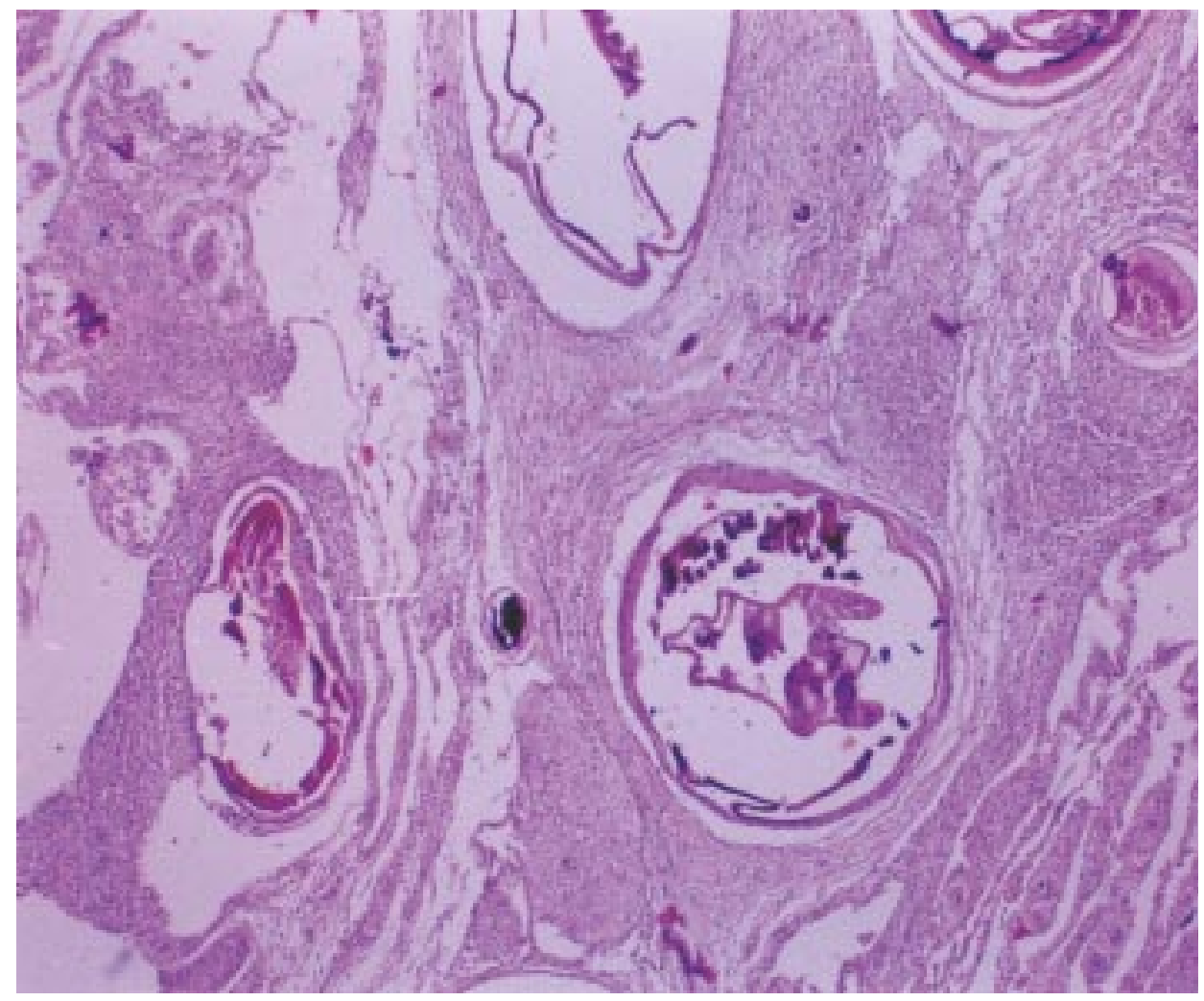

FIG. 7. Histopathological examination of the wall of peritoneal cavity of the infected fish showed severe infection with encysted plerocercoids with signs of fibrosis (H\&E stain $\times 200$ ).

\section{3 - Liver}

Liver inhabited infection with plerocercoid larvae stage of Trypanorhyncha of floriceps sp. were seen either free or formed encysted plerocercoid blastocysts. The infected liver appeared small size and firm in consistency with focal whitish necrotic areas (Fig. 8). While in other cases, hemorrhages in the liver was also observed. Histologically, the hepatocytes showed focal fibrosis replac- 


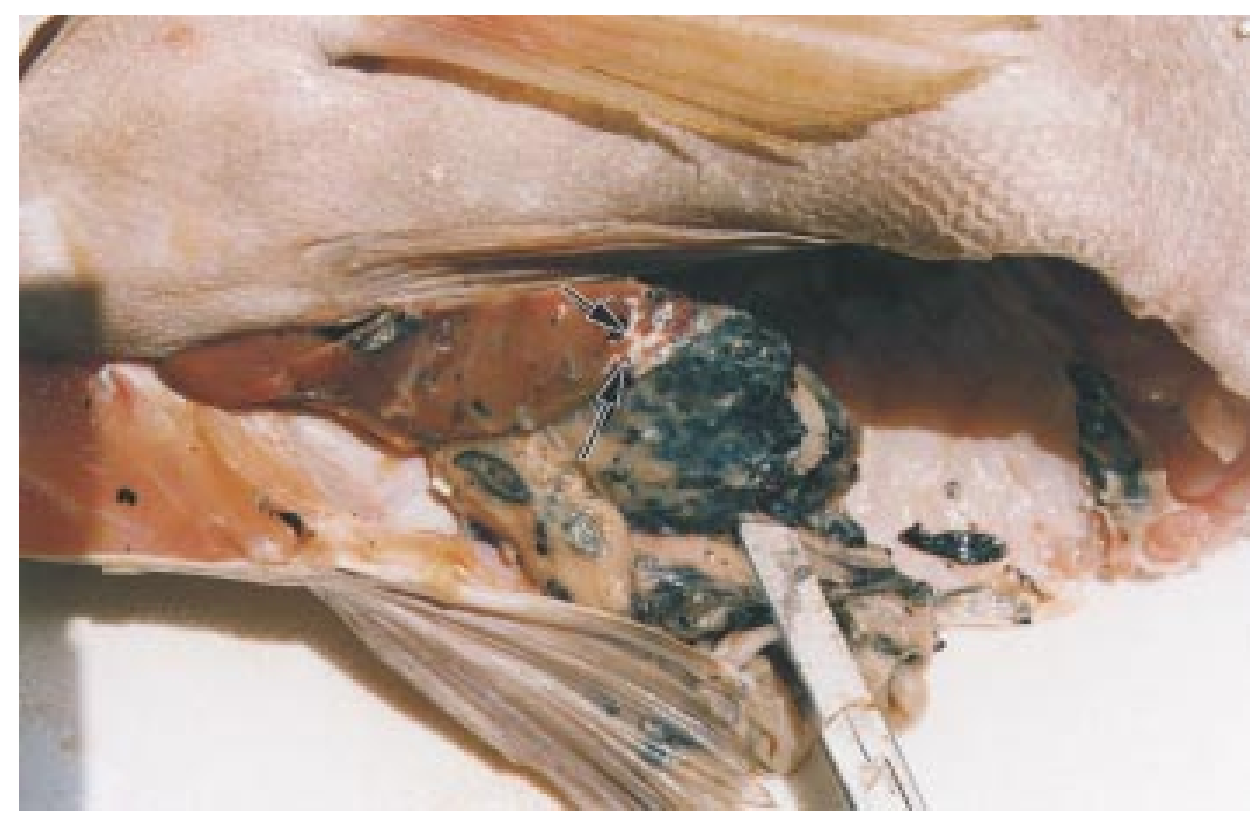

Fig. 8. Liver of the infected fish appeared small size, firm in consistency with focal white necrotic areas (arrows).

ing the necrotic hepatocytes. Focal hemorrhages with dilation of hepatic blood vessels and accumulation of golden yellow pigments (hemosiderine) were also noticed (Fig. 9).

\section{Discussion}

The occurrence of infestation with larval plerocercoids Trypanorhyncha (cestodes) of floriceps sp. in the examined fish could be due to feeding of these fish species on some kinds of crustacea (first intermediate host) that had been infected with procercoid stages of these parasite, a similar observation were reported by Korting (1984) and Al-Ghais and Kardousha (1994). While the presence of postlarval stage of floriceps sp. plerocercoids of Trypanorhyncha free in muscular tissues or encysted in body cavity could be due to species variation of the parasitic infection. These results were in harmony with the results reported by Palm (1997) who reported that metacestodes of 11 different Trypanorhynchs sp. occurred in the body cavity and mesenteries from 15 fish species and only 2 of them were in the flesh of fish from Northeast Brazilian coastal waters. Also AlGhais and Kardousha (1994) reported that plerocercoid of floriceps sp. on the 


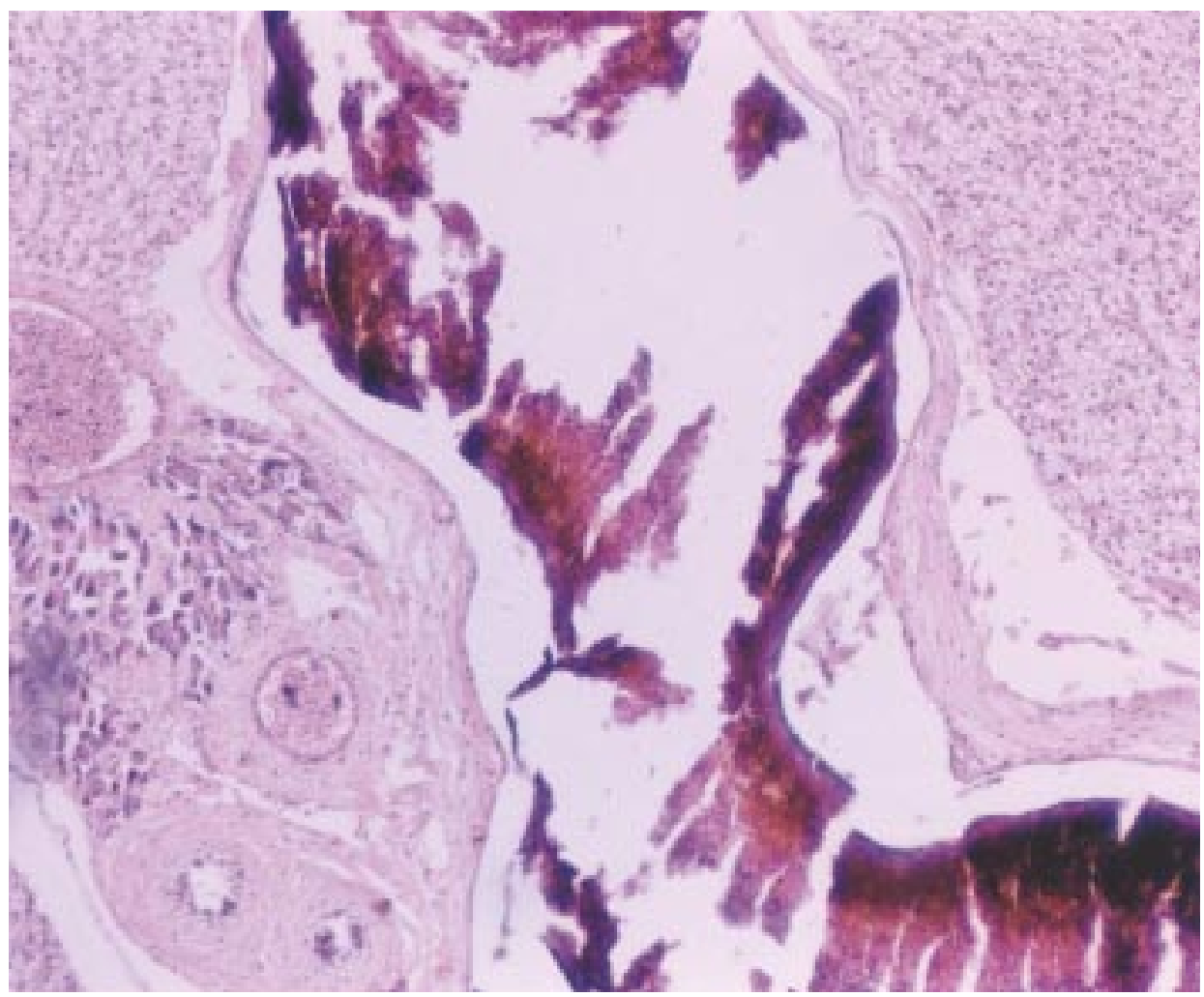

FIG. 9. Histopathological examination of the infected hepatocytes showed focal fibrosis around the parasitic worms larvae and dilation of the hepatic blood vessels (H\&E stained $\times 200$ ).

muscles surface and lining the body cavity in four marine fish species from the coastal water of U.A.E. It was evident from our results that the distribution and intensity of infestation in the flesh of the infective fish were various, it could be due to that several species of metacestodes of Trypanorchynchs prefer special localities with highly host specific. The rate of infection among the examined fish species was high specially in large sized fishes in contrast to the small size ones. This result could be due to the unavailability of the crustacean to young fishes and this also was in harmony with the results observed by Schlicht and McFarland (1967). The pronounced histopathological alteration in the muscular tissues of the infected fish species could be due to the mechanical damages induced by the strong movable contracting and reversible hooked tentacles. Similar pathological observations were also reported by Seyda (1976) and (Moser et al., 1984). The presence of dark to blackish spots in the flesh and deep brown to dark black envelop covering the blastocysts in the visceral activity indicated old infection. These results also agreed with Cosgrove (1975). The pronounced his- 
topathological effects in the liver and mesenteries were characterized by fibrosis, adhesion of the internal organs and severe degenerative and necrotic changes in the hepatocytes. Our results were in harmony to those described by (Mikhaflova et al., 1964) and (Bauer et al., 1977).

In conclusion, since Trypanorhyncha cestodes from the water of the Arabian Gulf are still a relatively poor studies, so further studies will be highly recommended to give complete understanding of Trypanorhyncha plerocercoids (Cestodes) infection among the most important commercial marine fish species. This will give us better recommendation and more precise advice with regard to such problems.

\section{Acknowledgement}

I would like to express my deep gratitude to Mr. F.A. Al-Jame, the general manager of Fisheries Research Center, El-Qataif, Eastern Province and all of my colleagues in fish diseases unit for their supports. Thanks are also extended to Dr. H. Palm, in the Institut Fur Meereskunde an der Universitat Kiel, Germany for his assistance in identification of the parasitic infestation.

\section{References}

Al-Ghais, S.M. and Kardousha, M.M. (1994) Study on some helminth parasites larvae common in Arabian Gulf fish: A Comparison between West and East coast of U.A.E., Arab Gulf. Scient. Res., 12(3): 559-571.

Bauer, O.N., Mussellus, V.A., Nikolaeva, V.M. and Strelkov, Y.A. (1977) Fish pathology, Idt Pishch Promyshl. (in Russian).

Campbell, R.A. and Beveridge, I. (1994) Order Trypanorhyncha Diesing, 1863. Keys to the Cestode Parasites of Vertebrates. In: Khalil, L.F., Jones, A. and Bray, R.A. (Eds.). Wallingford; CAB International: 51-148.

Carleton, H.M., Drury, R.A., Willington, E.A. and Comeron, H. (1962) cited from Carleton, Histological techniques, 4th Ed., Oxford Univ. Press, N. 4, Toronto.

Cosgrove, G.E. (1975) Parasites in tissue section: Recognition and reaction. In: The pathology of fishes (W.E. Ribelin and Magaki, eds.), pp. 205-245.

Deardorff, T., Raybourne, R.B. and Mattis, T.E. (1984) Infection with plerocerci (cestoda) in Hawaiian fishes of commercial importance, Sea Grant Quarterly, 6: 1-6.

El-Naffar, M.K.I., Gobashy, A., El-Etreby, S.G., Kardousha, M.M. (1992) General survey of helminth parasite genera of Arabian Gulf fishes (Coast of United Arab Emirates), Arabian Gulf J. Scient. Res., 10(2): 99-110.

Korting, W. (1984) Larval cyclophyllidean cestodes in carp and tench. Bull. Eur. Ass. Fish Pathol., 4(3): 40-41.

Lucky, Q. (1977) Methods for the diagnosis of fish diseases. American Publishing Co., Pvt. Ltd., New York.

Mikhailova, I.G., Prazhikov, E.V. and Prusevich, T.O. (1964) Morphological changes in the fish tissue arround the larvae of some parasitic worms. Tr. Murm. Morsk. Biol. Inst., 5: 251-264 (in Russian). 
Moser, M., Sakanari, J., Wellings, S. and Lindstrom, K. (1984) Incompatibility between San Francisco striped bass (Morone Saxatilis Walbum), and the metacestode, Lacist orhynchus tenui (beneaen, 1858), J. Fish Dis., 7: 397-400.

Oppenheimer, C.H.I. (1962) On marine fish diseases "Fish as Food" (G. Borgstrom, ed.), vol. 2: 541, Academic Press, New York.

Overstreet, R.M. (1977) Pocllancistrium caryophyllum and other trypanorhynch cestode plerocercoids from the musculature of cynsion nebulosus and other Sciaeni fish in the Gulf of Mexico. J. Parasitolo., 63: 780-787.

Palm, H.W. (1997) An alterative classification of trypanorchynch of limited importance. Systematic Parasitology, 37: 81-92.

Peterson, E., Palm, H., Moller, M. and Cruz, M.A. (1993) Flesh parasites of fish from central Philippine water. Aquatic Org., vol. 15: 81-86.

Reimer, L.W. (1997) Larvaen der Trypanorhynchs in Fischflesish Wiss, Z. pacdagog, Ochach, Liselotte Hermann, Gust row, 2: 207-211.

Schlicht, F.G. and McFarland, W.N. (1967) Incidence of Trypanorhynchan plerocercoids in some Texas Coast sciaenid fishes, Contrib. Mar. Sci., 12: 101-112.

Seyda, M. (1976) On a case of a mass invasion of cestode Gymnorhynchus gigas (Cuvier, 1817) larvae in muscles of brama rall (Bloch, 1791), Acta. Itchthyol. Piscatoria, 6: 59-65. 


\title{
التغير ات النسيجية المرضية فى بعض الأسماك البحرية من مياه الخليج العربى نتيجة للإصابة بيرقات ديدان الترايبانورينكا (سستودا)
}

\author{
مصطفى محمد إبر اهيم \\ معهد بحوث صحة الحيو ان - بالدقي - القاهرة - مصر إريم
}

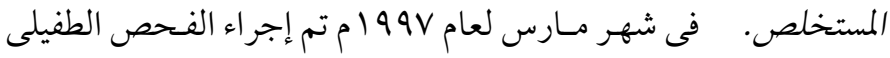

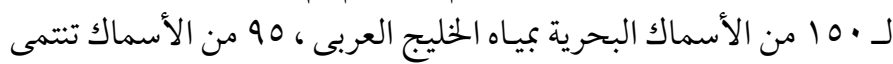

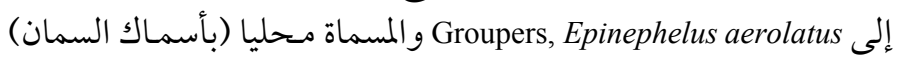

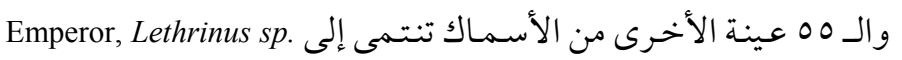

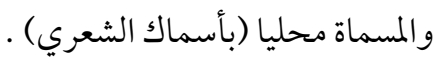

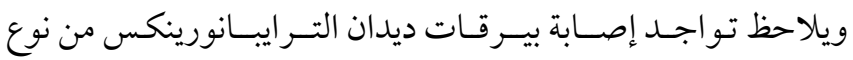

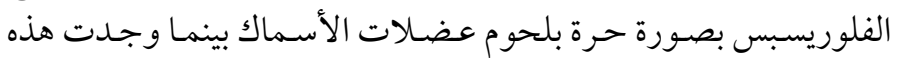

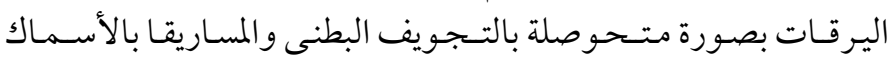
المصابـة . المرقات بصاب

وكانت نسبة الإصابة بين أسماك الشعري (0و ع ب\%) أعلى منها بين

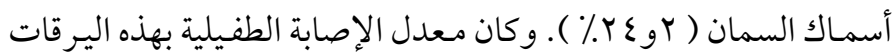

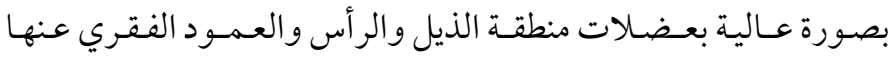

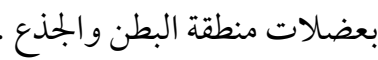

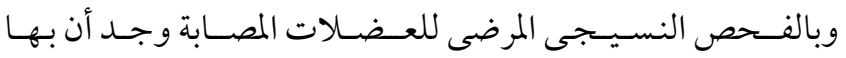

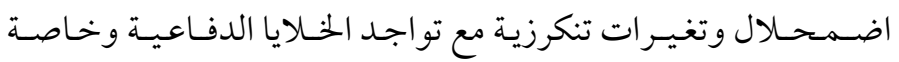

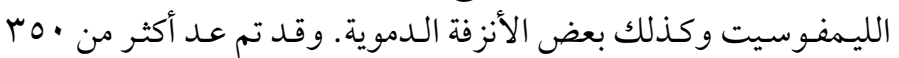

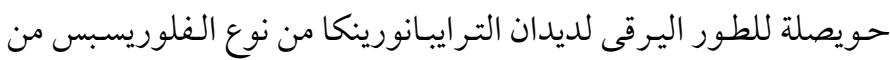

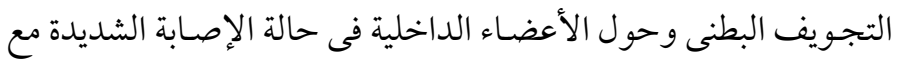
ظهور علامات الالتصاقات و التليف بهم . 